\title{
Sphaeromyxa artedielli sp. n. (Myxozoa: Sphaeromyxidae), a parasite of sculpins (Cottidae) in northern Norway
}

\author{
Egil Karlsbakk ${ }^{1}$, Ann-Cathrine Bårdsgjære Einen ${ }^{1}$ and Pavla Bartošová ${ }^{2}$
}

${ }^{1}$ Institute of Marine Research, Bergen, Norway;

${ }^{2}$ Institute of Parasitology, Biology Centre of the Academy of Sciences of the Czech Republic, České Budějovice, Czech Republic

\begin{abstract}
Sphaeromyxa artedielli sp. n. is described from the gall bladder of the Atlantic hookear sculpin Artediellus atlanticus Jordan et Evermann (Cottidae; type host) from northern Norway. The parasite was also found to infect Triglops murrayi Günther (Cottidae). Spores are produced in disporic pansporoblasts in large flat plasmodia. Spores are straight and fusiform with truncated ends, and measure 16.5-18.7 $\mu \mathrm{m} \times 4.9-6.2 \mu \mathrm{m}$. Valves are thick, striated and suture line is straight. Two equal ovoid polar capsules measure 4.2-6.8 $\mu \mathrm{m} \times 2.9-4.4 \mu \mathrm{m}$ and contain irregularly folded polar filaments. Distinctive features include spore shape and size, spore length/width relationship, striated valves, equal polar capsules and a short intercapsular distance. Sphaeromyxa bonaerensis Timi et Sardella, 1998, Sphaeromyxa cannolii Sears, Anderson et Greiner, 2011, and Sphaeromyxa sevastopoli Naidenova, 1970 produce straight spores with truncated ends that are of similar length as those of the new species. Sphaeromyxa cannolii differs in showing smooth spores with unequal polar capsules. The new species differs from $S$. bonaerensis and $S$. sevastopoli in significantly wider spores and polar capsules. Sphaeromyxa balbianii Thélohan, 1892, a species originally described with significantly smaller spores than $S$. artedielli sp. n., has previously been recorded from $T$. murrayi. We show that $S$. artedielli sp. n. differs from $S$. balbianii from the type host Gaidropsarus vulgaris (Cloquet) by its SSU rDNA sequence, and suggest that Atlantic records of Sphaeromyxa spp. from $T$. murrayi represent $S$. artedielli $\mathrm{sp}$. n. The closest relative to $S$. artedielli $\mathrm{sp}$. n. according to the SSU rDNA sequences, S. longa Dunkerly, 1921, differs clearly by spore size and shape. In the SSU rDNA-based phylogenetic analyses, S. artedielli sp. n. groups with other Sphaeromyxa spp. with straight spores and truncated ends in a clade that represents a sister-group to Sphaeromyxa spp. with arcuate spores and rounded ends. Our results indicate that an SSU rDNA pseudogene is present in S. balbianii.
\end{abstract}

Keywords: Myxosporeans, marine fish, new species, Artediellus atlanticus, Triglops murrayi, SSU rRNA gene sequences, pseudogene, northern Atlantic Ocean, Sphaeromyxa balbianii

The genus Sphaeromyxa Thélohan, 1892 currently contains 46 species, which are coelozoic parasites in the bile ducts and gall bladder of marine fishes. Most species produce a large number of spores in very large flat plasmodia (up to $22 \mathrm{~mm}$ in diameter). The spores contain two polar capsules, one at each spore end. These contain a polar filament, which is thick when extruded, broad at the base and tapering towards the ends. The polar filament in Sphaeromyxa spp. is folded upon itself several times inside the polar capsule, whereas it is thin and coiled in other myxosporeans (Lom and Dyková 2006).

Different Sphaeromyxa spp. produce spores of two main types: either straight fusiform spores with oval polar capsules and usually truncate ends, or arcuate spores with pyriform polar capsules that usually have rounded spore ends. Laird (1953) referred to these as members of the 'balbianii' and 'incurvata' groups, respectively. Separation of the species in these two groups is also supported by phylogenetic studies (Kristmundsson and Freeman 2013, Whipps and Font 2013).
During a survey on myxosporean diversity of Norwegian marine fishes, infections with a Sphaeromyxa species belonging to the 'balbianii' group were discovered in two sculpin species caught in relatively deep waters in northern Norway. This species was found to be new to science and is described below.

\section{MATERIALS AND METHODS}

The marine sculpins Artediellus atlanticus Jordan et Evermann and Triglops murrayi Günther were collected by bottom trawl during a research cruise along the coast of northern Norway with RV 'Helmer Hanssen' from 17 October to 12 November 2011 (Table 1). The sculpins were immediately examined post capture. Fresh bile samples were examined in a microscope (Olympus CX41) equipped with a digital camera (Olympus SC30) and digital image series of the spores and plasmodia were taken. Plasmodia and spore measurements were taken from the images using the Image $\mathbf{J}$ software. Air dried smears were kept from infected samples; these were stained with Hemacolor ${ }^{\circledR}$ (Merck Millipore, Billerica, MA). Ethanol-fixed (96\%) samples 
Table 1. Specimens of the sculpins Artediellus atlanticus (AA) and Triglops murrayi (TM) found infected with Sphaeromyxa artedielli sp. $\mathrm{n}$. in the gall bladder.

\begin{tabular}{|c|c|c|c|c|c|c|c|}
\hline $\begin{array}{l}\text { Sequence } \\
\text { isolate }\end{array}$ & Date & Position & $\begin{array}{l}\text { Depth } \\
(\mathrm{m})\end{array}$ & Host & $\begin{array}{l}\text { Total length of } \\
\text { host fish (mm) }\end{array}$ & $\begin{array}{l}\text { Stages of } S \text {. artedielli } \\
\text { observed in bile }\end{array}$ & $\begin{array}{c}\text { GenBank } \\
\text { Accession No. }\end{array}$ \\
\hline HH-3 & 30 October 2011 & $70^{\circ} 14.4^{\prime} \mathrm{N}, 18^{\circ} 28.2^{\prime} \mathrm{E}$ & $181-195$ & AA & 90 & spores, plasmodia & KF135220 \\
\hline НH-73 & 30 October 2011 & $70^{\circ} 14.4^{\prime} \mathrm{N}, 18^{\circ} 28.2^{\prime} \mathrm{E}$ & $181-195$ & $\mathrm{AA}$ & 95 & plasmodia & KF135222 \\
\hline HН-38 & 5 November 2011 & $67^{\circ} 13.2^{\prime} \mathrm{N}, 11^{\circ} 14.5^{\prime} \mathrm{E}$ & $177-184$ & $\mathrm{TM}$ & 95 & spores, plasmodia & KF135223 \\
\hline HН-39 & 5 November 2011 & $67^{\circ} 39.9^{\prime} \mathrm{N}, 11^{\circ} 29.0^{\prime} \mathrm{E}$ & $145-151$ & $\mathrm{TM}$ & 102 & spores, plasmodia & KF135224 \\
\hline
\end{tabular}

of the new species spores and plasmodia were kept for subsequent DNA isolation. Ethanol-fixed samples of Sphaeromyxa balbianii spores (isolate M0167) from the type host, Gaidropsarus vulgaris (Cloquet), were available at the Laboratory of Fish Protistology, Institute of Parasitology, BC ASCR and originated from the same sampling lot in Scotland as $S$. balbianii sample (isolate M0312), for which SSU and LSU rDNA sequences have been published previously (Bartošová et al. 2009).

DNA was extracted from dried $\left(60^{\circ} \mathrm{C}\right.$, ethanol-free) samples of myxosporean spores and plasmodia using the DNeasy ${ }^{\circledR}$ Tissue Kit protocol for animal tissues (Qiagen, Hilden, Germany). The following forward/reverse primers were used for PCR to amplify the SSU rDNA of $S$. artedielli: Erib1/1430rev, MyxF2/ Myxgen4R and Myxgen4F/RosR2 (see Barta et al. 1997, Kent et al. 2000, Freeman et al. 2008, Køie et al. 2008), with annealing temperatures of $52^{\circ} \mathrm{C}, 58^{\circ} \mathrm{C}$ and $52^{\circ} \mathrm{C}$, respectively. The novel $S$. balbianii sequences were obtained with the Erib1/ Erib10 primers (Barta et al. 1997) with an annealing temperature of $50^{\circ} \mathrm{C}$.

PCR amplifications were performed in a total volume of $50 \mu \mathrm{l}$ using $2 \mu \mathrm{l}$ of template DNA and a reaction mixture consisting of $10 \mu 15 \times$ PCR buffer, $3 \mu 125 \mathrm{mM} \mathrm{MgCl}_{2}, 5 \mu 110 \mathrm{mM}$ dNTP, $2 \mu 1$ $(10 \mathrm{mM})$ of the forward and reverse primer, $2 \mathrm{U}$ of thermostable DNA polymerase (GoTaq ${ }^{\circledR}$, Promega, Madison, WI), and $26 \mu 1$ $\mathrm{dH}_{2} \mathrm{O}$. PCR conditions were used as previously described (Køie et al. 2008). PCR products were cleaned with ExoSAP-IT ${ }^{\circledR}$ (Affymetrix Inc., Santa Clara, CA) and then sequenced using the BigDye ${ }^{\circledR}$ Terminator v3.1 Cycle Sequencing Kit. The sequencing of both sense and anti-sense strands was done using the PCR amplification primers. The sequence data were assembled with the Vector NTI 11 software (Invitrogen, Carlsbad, CA) and GenBank searches were done with Blast (2.0).

The phylogenetic relationships between $S$. artedielli and other Sphaeromyxa spp. were inferred by maximum likelihood (ML) and maximum parsimony (MP) analyses using MEGA 5.1 (Tamura et al. 2011). SSU rDNA sequences were aligned with Clustal W (AlignX, Vector NTI) with default settings. A GTR $+\Gamma+$ I model of nucleotide substitution was selected (AICc) for the ML analysis. Nodal supports were calculated using 500 bootstrap replications for both analyses.

\section{RESULTS}

\section{Sphaeromyxa artedielli $\mathrm{sp} . \mathrm{n}$.}

Figs. 1, 2

Plasmodia large, flat, round to oval or elongate, sometimes bilobed. Small plasmodia rounded to bilobed, often with a brushy region at one side (filopodia/rhizoids) (Fig. 1B). Large polysporic plasmodia with distinct
Table 2. Measurements of spores of Sphaeromyxa artedielli sp. n. from Artediellus atlanticus (type host) and from Triglops murrayi.

\begin{tabular}{lccccccccccccc}
\hline Host & \multicolumn{3}{c}{ Artediellus atlanticus } & \multicolumn{5}{c}{ Triglops murrayi } \\
\hline Measurement & \multicolumn{3}{c}{ Mean } & SD & Min Max & $\mathrm{N}$ & \multicolumn{4}{c}{ Mean } & SD & Min Max & N \\
\hline Length (L) & 17.8 & 0.5 & 16.5 & 18.7 & 31 & 17.4 & 0.7 & 14.9 & 18.9 & 48 \\
Width (W) & 5.4 & 0.3 & 4.9 & 6.2 & 19 & 5.7 & 0.2 & 5.3 & 6.1 & 27 \\
Thickness & 5.4 & 0.3 & 4.9 & 6.1 & 14 & 5.7 & 0.3 & 5.1 & 6.3 & 21 \\
PC length & 5.6 & 0.4 & 4.2 & 6.8 & 64 & 5.5 & 0.3 & 4.5 & 6.3 & 96 \\
PC diameter & 3.5 & 0.3 & 2.9 & 4.4 & 63 & & 3.6 & 0.3 & 3.1 & 4.3 & 96 \\
PC-PC & 5.3 & 0.3 & 4.6 & 5.8 & 31 & 5.0 & 0.5 & 4.1 & 6.2 & 48 \\
End-dish diam- & 2.1 & 0.4 & 1.2 & 3.1 & 59 & 2.3 & 0.4 & 1.3 & 3.0 & 95 \\
eter & & & & & & & & & & \\
ID/PC index & 0.9 & 0.1 & 0.8 & 1.2 & 31 & 0.9 & 0.1 & 0.7 & 1.2 & 48 \\
L/W index & 3.3 & 0.2 & 3.0 & 3.7 & 17 & 3.1 & 0.2 & 2.8 & 3.4 & 25 \\
\hline
\end{tabular}

$\mathrm{SD}$ - standard deviation; $\mathrm{N}$ - number of measurements; $\mathrm{PC}$ - polar capsule; ID/PC index - ratio of intercapsular distance (PC-PC) and mean $\mathrm{PC}$ length of each spore.

transparent ectoplasm, measuring $3-8 \mu \mathrm{m}$ in thickness at plasmodium margin, with distinct mucoid zone externally, 3.5-5.5 $\mu \mathrm{m}$ in thickness (Fig. 1A). Plasmodia without spores $(\mathrm{N}=33)$ up to $107 \mu \mathrm{m}$ in diameter; plasmodium with immature spores measuring $450 \times 440 \mu \mathrm{m}$. Plasmodia with mature spores $0.5-2.2 \mathrm{~mm}$ in diameter (area $0.18-3.0 \mathrm{~mm}^{2}$ ). A plasmodium with area $1.65 \mathrm{~mm}^{2}$ estimated to contain about 4700 spores. Pansporoblasts distinct, vacuole-like, round to oval, each containing two spores (Fig. 1A). Pansporoblasts with spores $17-25 \mu \mathrm{m}$ in mean diameter $(\mathrm{N}=12)$.

Spore measurements in Table 2. Spores fusiform with truncate ends. Valves with 6-7 faint striations, parallel to longitudinal axis of spore. Spore thickness equal to width. Valves thick, $0.4-0.5 \mu \mathrm{m}$ (mean $0.44 ; \mathrm{N}=33$ ). Suture line indistinct, straight (Fig. 2C), occasionally slightly sigmoid (Fig. 2D). Polar capsules at each spore end, equal, ovoid, often with truncated apical end. Polar filament irregularly arranged in 1.5-2.5 visible folds/coils, roughly parallel to longitudinal axis of polar capsule. Nuclei of capsulogenic cells distinct, positioned posterolaterally to polar capsules in valvular view. Intercapsular distance equal to or shorter than polar capsule length. Sporoplasm binucleate. Immature spores with more pointed Myxidium-like ends, longer $(18-20 \mu \mathrm{m})$ than mature spores. 


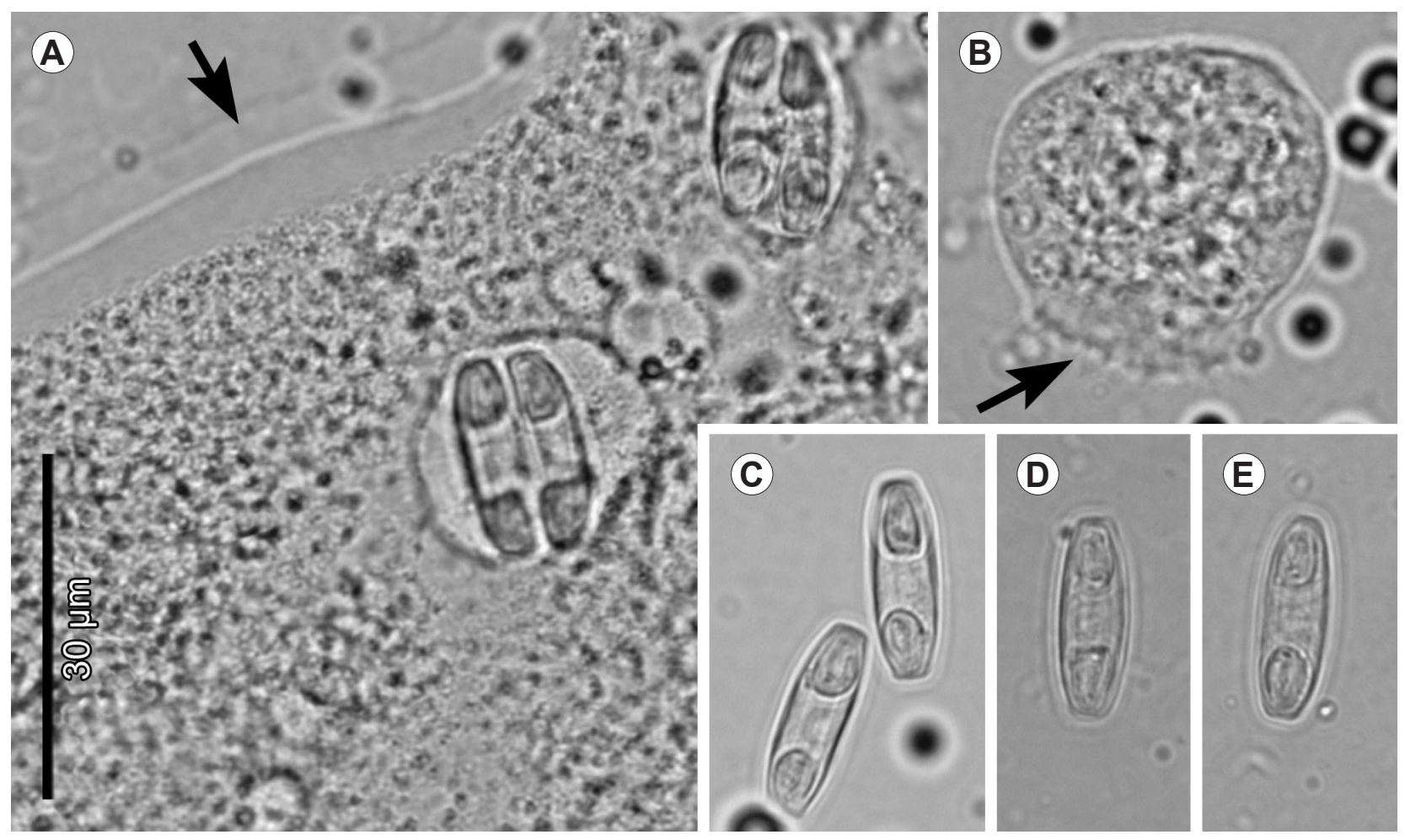

Fig. 1. Images of fresh Sphaeromyxa artedielli sp. n. plasmodia and spores from the bile of sculpins, Triglops murrayi (A, B, D, E) and Artediellus atlanticus (C). A - margin of a large plasmodium showing granular endoplasm with disporic pansporoblasts and transparent ectoplasm; a mucoid zone is seen outside the ectoplasm (arrow); B - small plasmodium with a brushy zone (arrow - rhizoids); $\mathbf{C}-\mathbf{E}$ - spores. Scale bar is same for A-E.

A

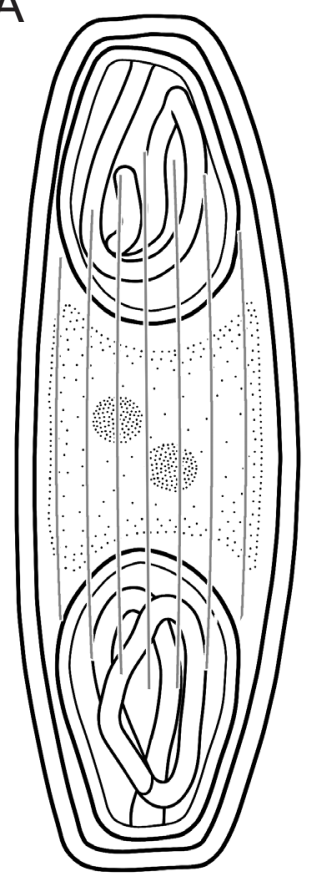

$\mathrm{B}$

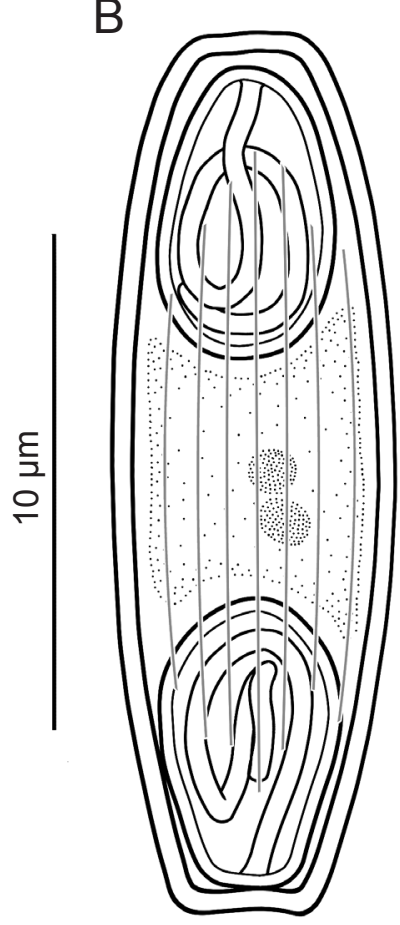

C

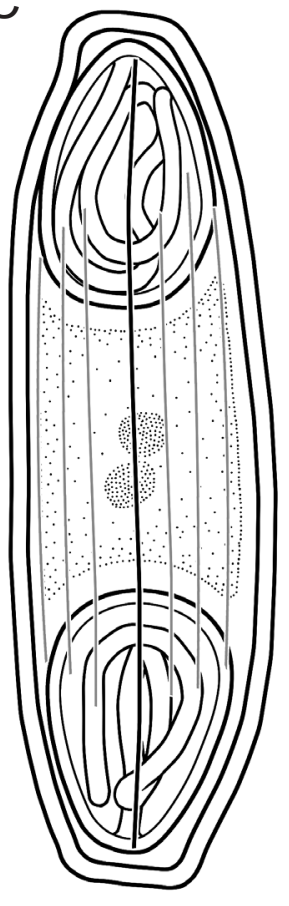

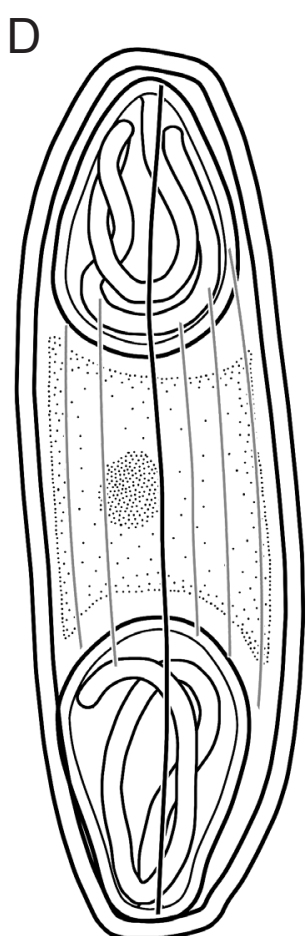

Fig. 2. Line drawings of Sphaeromyxa artedielli sp. n. spores from Artediellus atlanticus. A, B - valvular view; C, D - sutural view (D - spore with slightly sigmoid suture line). 
Table 3. Sphaeromyxa spp. having straight spores with truncate flattened ends. Data for $S$. artedielli sp. n. given from both hosts (Artediellus atlanticus and Triglops murrayi, $\mathrm{N}=79$ ).

\begin{tabular}{|c|c|c|c|c|c|c|c|c|c|}
\hline Species & $\begin{array}{l}\text { Type host } \\
\text { (family) }\end{array}$ & Locality & Length & Width & PC length & PC width & $\begin{array}{l}\text { ID/PC } \\
\text { Index* }\end{array}$ & Valves & Reference \\
\hline Sphaeromyxa artedielli sp. $\mathrm{n}$. & $\begin{array}{l}\text { Artediellus atlanticus, } \\
\text { Triglops murrayi } \\
\text { (Cottidae) }\end{array}$ & $\begin{array}{l}\text { Northern } \\
\text { Norway }\end{array}$ & $\begin{array}{l}14.9-18.9 \\
(17.5)\end{array}$ & $\begin{array}{l}4.9-6.2 \\
(5.6)\end{array}$ & $\begin{array}{l}4.2-6.8 \\
(5.6)\end{array}$ & $\begin{array}{l}2.9-4.4 \\
(3.6)\end{array}$ & $\begin{array}{l}0.7-1.2 \\
(0.9)\end{array}$ & Str & $\begin{array}{l}\text { Present } \\
\text { study }\end{array}$ \\
\hline $\begin{array}{l}\text { Sphaeromyxa balbianii } \\
\text { Thélohan, } 1892\end{array}$ & $\begin{array}{l}\text { Gaidropsarus vulgaris } \\
\text { (Lotidae) }\end{array}$ & $\begin{array}{l}\text { Roscoff, } \\
\text { France }\end{array}$ & $\begin{array}{l}13-16 \\
15\end{array}$ & 5 & N/A & N/A & $>1.9$ & Str & $\begin{array}{l}\text { Thélohan } \\
\text { 1892, } 1895\end{array}$ \\
\hline $\begin{array}{l}\text { Sphaeromyxa bonaerensis } \\
\text { Timi et Sardella, } 1998\end{array}$ & $\begin{array}{l}\text { Anchoa marini } \\
\text { (Engraulidae) }\end{array}$ & $\begin{array}{l}\text { Mar del Plata, } \\
\text { Argentina }\end{array}$ & $\begin{array}{l}16.5-18.8 \\
(17.3)\end{array}$ & $\begin{array}{l}3.7-4.8 \\
(4.5)\end{array}$ & $\begin{array}{l}3.0-4.5 \\
(4.1)\end{array}$ & $\begin{array}{l}1.9-3.3 \\
(2.8)\end{array}$ & $1.1-1.3$ & Str & $\begin{array}{l}\text { Timi and } \\
\text { Sardella } \\
1998\end{array}$ \\
\hline $\begin{array}{l}\text { Sphaeromyxa cannolii } \\
\text { Sears, Anderson et Greiner, } \\
2011\end{array}$ & $\begin{array}{l}\text { Hippocampus erectus } \\
\text { (Syngnathidae) }\end{array}$ & Gulf of Mexico & $\begin{array}{r}017-18 \\
(17.6)\end{array}$ & $\begin{array}{l}5-6 \\
(5.5)\end{array}$ & $\begin{array}{l}4.2-5.4 \\
(4.8)+ \\
4.4-5.9 \\
(5.2)\end{array}$ & $\begin{array}{l}2.4-3.3 \\
(3.0)+ \\
2.4-3.5 \\
(2.8)\end{array}$ & $1.1-1.3$ & $\mathrm{Sm}$ & $\begin{array}{l}\text { Sears et al. } \\
2011\end{array}$ \\
\hline $\begin{array}{l}\text { Sphaeromyxa japonica } \\
\text { Aseeva, } 2002\end{array}$ & $\begin{array}{l}\text { Triglops murrayi } \\
\text { (Cottidae) }\end{array}$ & Japan Sea & $18.5-23.7$ & $4.3-4.5$ & $5.0-6.3$ & 3.8 & $1.6-2.1$ & Str & $\begin{array}{l}\text { Aseeva } \\
2002\end{array}$ \\
\hline $\begin{array}{l}\text { Sphaeromyxa magna } \\
\text { Zhukov, } 1964\end{array}$ & $\begin{array}{l}\text { Liparis gibbosus } \\
\text { (Liparidae) }\end{array}$ & Bering Sea & 23 & 6.4 & 8.5 & 4 & $1.0-1.1$ & Str & $\begin{array}{l}\text { Zhukov } \\
1964\end{array}$ \\
\hline $\begin{array}{l}\text { Sphaeromyxa minuta } \\
\text { Polyansky, } 1955\end{array}$ & $\begin{array}{l}\text { Hippoglossus hippoglossus } \\
\text { (Pleuronectidae) }\end{array}$ & Barents Sea & $13.5-16.2$ & $2.7-3.6$ & $2.7-4.5$ & N/A & $1.4-1.6$ & $\mathrm{Sm}$ & $\begin{array}{l}\text { Polyansky } \\
1955\end{array}$ \\
\hline $\begin{array}{l}\text { Sphaeromyxa opisthopterae } \\
\text { Sarkar, } 1999\end{array}$ & $\begin{array}{l}\text { Opisthopterus tardoore } \\
\text { (Clupeidae) }\end{array}$ & Bay of Bengal & $\begin{array}{l}9-12.7 \\
(11.5)\end{array}$ & $\begin{array}{l}3.3-4.5 \\
(3.9)\end{array}$ & $\begin{array}{l}2.6-3.8 \\
(3.6)\end{array}$ & $\begin{array}{l}1.8-3.0 \\
(2.8)\end{array}$ & $1.1-1.8$ & Str & Sarkar 1999 \\
\hline $\begin{array}{l}\text { Sphaeromyxa schulmani } \\
\text { Kovaleva et Gaevskaya, } 1982\end{array}$ & $\begin{array}{l}\text { Salilota australis } \\
\text { (Moridae) }\end{array}$ & SW Atlantic & $18.6-20.0$ & $4-6.0$ & $4.6-6.0$ & $2.6-3.3$ & $1.3-1.8$ & $\mathrm{Sm}$ & $\begin{array}{l}\text { Kovaleva } \\
\text { and } \\
\text { Gaevskaya } \\
1982\end{array}$ \\
\hline $\begin{array}{l}\text { Sphaeromyxa sevastopoli } \\
\text { Naidenova, } 1970\end{array}$ & $\begin{array}{l}\text { Neogobius fluviatilis } \\
\text { (Gobiidae) }\end{array}$ & Black Sea & $18.2-18.3$ & $4.2-4.6$ & $5.6-5.8$ & $3.1-3.3$ & $0.9-1.3$ & Str & $\begin{array}{l}\text { Naidenova } \\
1970\end{array}$ \\
\hline $\begin{array}{l}\text { Sphaeromyxa zaharoni } \\
\text { Diamant, Whipps et Kent, } \\
2004\end{array}$ & $\begin{array}{l}\text { Pterois miles } \\
\text { (Scorpaenidae) }\end{array}$ & Red Sea & $\begin{array}{l}13.7-15.1 \\
(14.5)\end{array}$ & $\begin{array}{l}4.2-5.5 \\
(4.8)\end{array}$ & $\begin{array}{l}3.3-5.6 \\
(4.8)\end{array}$ & $\begin{array}{l}2.5-4.0 \\
(3.4)\end{array}$ & $1.0-1.3$ & Str & $\begin{array}{l}\text { Diamant et } \\
\text { al. } 2004\end{array}$ \\
\hline
\end{tabular}

PC - Polar capsule; ID/PC index - the ratio of the intercapsular distance to the mean PC length; Str - striated valves; Sm - smooth valves; N/A - not given; *source: Thélohan 1895 - plate VIII Figs. 58, $59(\mathrm{~N}=2)$; Timi and Sardella 1998 - Figs. 1, $4(\mathrm{~N}=2)$; Sears et al. 2011 - Fig. 1b $(\mathrm{N}=4)$; Aseeva 2002 - Fig. $1(\mathrm{~N}=6)$; Zhukov 1964 - Fig. $26(\mathrm{~N}=2)$; Polyansky 1955 - Fig. $9(\mathrm{~N}=4)$; Sarkar 1999 - Fig. $1(\mathrm{~N}=7)$; Kovaleva and Gaevskaya 1982 - Fig. $1(\mathrm{~N}=4)$; Naidenova 1970 - Fig. $2(\mathrm{~N}=3)$; Diamant et al. 2004 - Figs. 1, 5, $6(\mathrm{~N}=6)$.

Type host: Artediellus atlanticus Jordan et Evermann, (Scorpaeniformes: Cottidae).

Other host: Triglops murrayi Günther (Scorpaeniformes: Cottidae).

Type loc a lity: Off Grøtøya, Troms county, Northern Norway $\left(70^{\circ} 24^{\prime} \mathrm{N}, 18^{\circ} 47^{\prime} \mathrm{E}\right.$; depth of $\left.181-195 \mathrm{~m}\right)$.

Site of infection: Gall bladder.

Prevale n c e: Artediellus atlanticus $-100 \%(\mathrm{n}=4)$; Triglops murrayi $-75 \%(\mathrm{n}=4)$.

Deposition of specimens: University Museum Bergen, Zoological Collections; syntype slide, stained smear of S. artedielli sp. n. from $A$. atlanticus (HH-3; ZMBN-91884), ethanol sample (HH-3; ZMBN-91885). Vouchers: stained smear from T. murrayi (HH-39; ZMBN-91886), ethanol sample (HH-39, ZMBN-91887).

E t y m o log y: Named after the generic name of the type host.

Remarks. Comparative measurements of $S$. artedielli and similar members of the 'balbianii' group are provided in Table 3. Sphaeromyxa diacanthusa Sarkar, 2004, S. intermediata Moser et Noble, 1977, S. pultai Tripathi, 1954, and $S$. reinhardti Jameson, 1929 were also described as having truncate ends, but the spore ends in these species are more rounded (convex) than in the species listed in Table 3. Sphaeromyxa artedielli shows similar spore length as $S$. bonaerensis Timi et Sardella, 1998, S. cannolii Sears,
Anderson et Greiner, 2011, and S. sevastopoli Naidenova, 1970. From these, the new species differs in spore width (narrower in $S$. bonaerensis and $S$. sevastopoli), polar capsule size (smaller in $S$. bonaerensis), polar capsule diameter (smaller in $S$. sevastopoli) or in having surface striations and equal-sized polar capsules (smooth valves and unequal polar capsules in S. cannolii). The hosts and geographic locations for these species also differ.

Sphaeromyxa minuta Polyansky, 1955 was described from halibut, Hippoglossus hippoglossus (Linnaeus), in the same region (Barents Sea). This species shows shorter and markedly narrower spores than $S$. artedielli and smaller polar capsules. Polyansky (1955) obtained measurements from stained smears, a method that could cause spore shrinking. However, he did not observe striations on the spore valves and the relative proportions of the spores such as the ID/PC index differs clearly.

Sphaeromyxa spp. in the 'balbianii' group have previously been detected in Arcto-boreal cottids in both the North Atlantic (Shul'man 1966, Lom 1970, 1984, Khan et al. 1986, Lom and Dyková 1992) and the North Pacific (Zhukov 1964, Aseeva 2002). Sphaeromyxa japonica Aseeva, 2002 from sculpins in the Sea of Japan shows larger spores, but also clearly differs in the relative extent of the intercapsular distance (ID/PC index $>1.6$ in S. japonica). 
Lom $(1970,1984)$ presented images of S. balbianii Thélohan, 1892 from Triglops murrayi, according to Khan et al. (1986) caught in the Grand Banks area off Newfoundland (see Lom and Laird 1969). Khan et al. (1986) also found $100 \%$ of T. murrayi $(\mathrm{n}=7)$ from southern Labrador and the Grand Banks area infected by S. balbianii. Based on the dimensions of $S$. balbianii given by Parisi, 1912, Khan et al. (1986) concurred with Lom's (1970) identification. However, the dimensions given by Parisi (1912) for S. balbianii from sardines, Sardina pilchardus (Walbaum), are larger than those of Thélohan (1892, 1895, see Table 3) from Gaidropsarus vulgaris (Cloquet) with spores measuring $15-20 \mu \mathrm{m} \times 5-6 \mu \mathrm{m}$ and polar capsules measuring $7 \mu \mathrm{m} \times 4.7 \mu \mathrm{m}$. These dimensions are more in agreement with those of $S$. artedielli and the images presented by Lom $(1970,1984)$ do suggest that they may represent the same species.

Lom and Dyková (1992) presented an image of S. magna Zhukov, 1964 from T. murrayi, presumably representing the same material previously identified as S. balbianii (see Lom 1970, 1984). Sphaeromyxa magna was originally described from a Pacific liparid fish and differs clearly from $S$. artedielli in spore dimensions but not in shape or relative proportions.

Other myxosporean species were not detected in the bile, and myxosporean spores were not observed in the urinary system of the studied sculpins.

\section{SSU rDNA sequences}

Sequences of $S$. artedielli sp. n. were obtained from all three sculpins infected with spores that were measured. Almost identical sequences were also obtained from isolates from two sculpins containing large flat plasmodia without spores. The three partial SSU rDNA sequences of S. artedielli from A. atlanticus were identical over 1809 positions compared, except for an ambiguous signal (double peak) at position 1139 (HH3, HH72). The two partial SSU rDNA sequences of $S$. artedielli from $T$. murrayi were also identical, except for ambiguous signals at positions 715 and 884 in HH38 (1883 positions compared). However, there were 19 unambiguous substitutions and one nt gap in the sequences from T. murrayi when compared to those from A. atlanticus (98.9\% identity, 1809 positions compared).

\section{Phylogenetic analyses}

The phylogenetic affinities of Sphaeromyxa artedielli sp. n. with other myxosporeans were firstly examined by ML analysis (GTR I + G) with 23 ingroup sequences (801 positions). The sequences were selected on the basis of Blast searches (Blastn and MegaBlast). The same relationships among Sphaeromyxa spp. were also observed in an analysis particularly restricted to sphaeromyxids as ingroups (Fig. 3). Both ML and MP analyses placed S. artedielli in a well supported clade with members of

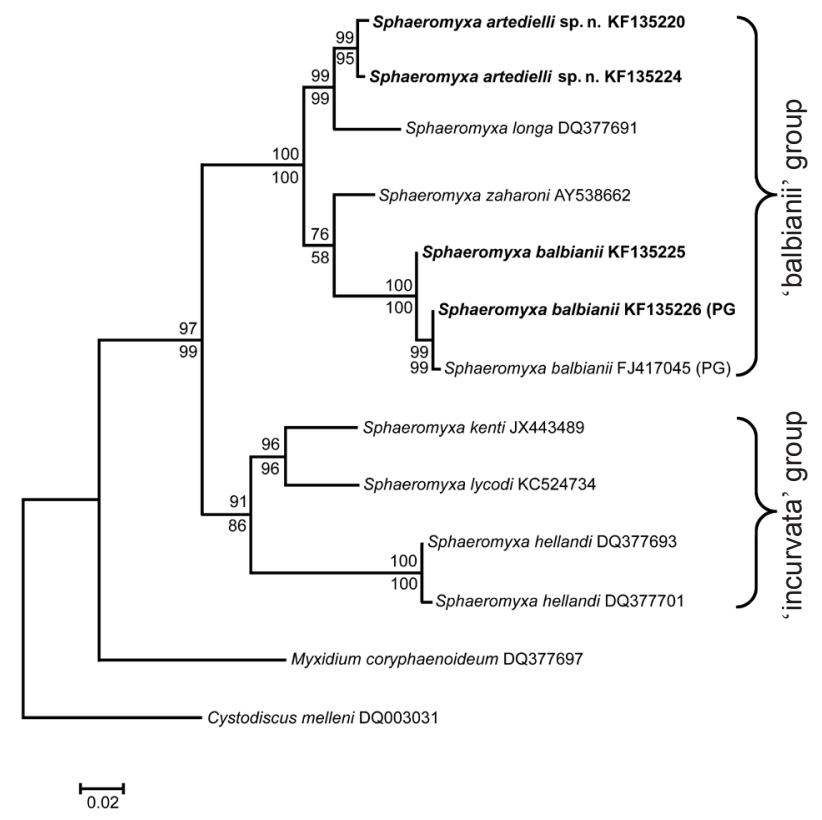

Fig. 3. The phylogenetic position of Sphaeromyxa artedielli sp. n. among other Sphaeromyxa spp. Maximum likelihood tree based on partial SSU rDNA sequences (869 positions), including 11 Sphaeromyxa SSU rDNA sequences as ingroups and Cystodiscus melleni and Myxidium coryphaenoideum as outgroups. Nodal supports are indicated for ML (upper) and MP (lower). PG - likely pseudogene sequences. New sequences obtained in the present study indicated in bold.

the 'balbianii' group, in a subclade containing S. longa Dunkerly, 1921. The members of the 'incurvata' group sequenced so far, Sphaeromyxa hellandi Auerbach, 1909, S. kenti Whipps et Font, 2013 and S. lycodi Kristmundsson et Freeman, 2013, constituted a second major clade of the genus.

\section{SSU rDNA variation in Sphaeromyxa balbianii}

Two sequence variants of $S$. balbianii SSU rDNA (GenBank Accession numbers KF135225-6) were identified by PCR with primers Erib1-Erib10. The primers amplified two fragments of a different length corresponding to $1977 \mathrm{bp}$ and $1480 \mathrm{bp}$. Their length difference was due to the presence of two indels. A long insertion (491 nt) within the longer sequence started from the conservative region positioned just after the end of the variable region 5 (V5) and ranged into V8 of the S. balbianii SSU rRNA gene. A second (6 nt) insertion also occurred in the V8 region. Besides the presence of these indels, the two sequences differed at 12 positions spread within the rest of the SSU rDNA.

\section{DISCUSSION}

The large, flat, polysporic plasmodia as observed in Sphaeromyxa artedielli $\mathrm{sp} . \mathrm{n}$. are the common type in the genus Sphaeromyxa - see Lom and Dyková (2006). 
The large plasmodia showed a clear ectoplasmic region, which was not apparent in small plasmodia. The latter showed regions with rhizoids, suggesting that they occur attached to the gall bladder epithelium. We observed a distinct mucoid layer external to the margin of the large plasmodia. Previous ultrastructural studies on Sphaeromyxa spp. suggest this may represent a zone with mucus penetrated with microvillosities of the plasmodium (Gracia et al. 1997, Lom 2004).

Most members of the 'balbianii' group show truncate spore ends. Sphaeromyxa artedielli spores observed from both the valvular and sutural views show this truncation, suggesting that the spore ends are disc-like. Since there are few good characters in the 'balbianii' group, the diameter of the disc is an additional feature that may be used in species discrimination. We also found the ratio of intercapsular distance to (mean) polar capsule length (ID/PC index) to be useful in distinguishing some species. This is a character that can be readily recognized in light microscopy or from images. The fine longitudinal striations seen on the spores represent clefts between ridges on the valves (Lom 2004).

To date rDNA sequences of six Sphaeromyxa species have been deposited in GenBank. The SSU rDNA sequences of $S$. artedielli show the highest percentage of identity (aligned positions, neglecting gaps) with $S$. longa (DQ377691; 95.7\%; 903 positions compared), S. zaharoni (AY538662; 94.6\%; 1867 positions compared) and S. balbianii (KF135225-6, FJ417045; 94.6\%, 94.6\%, $93.3 \% ; 1806,1309$ and 1116 positions compared, respectively). Our results show that $S$. artedielli is distinguished from $S$. balbianii, with which it may have been misidentified in the past (see above), by both morphological and molecular differences. The closest relative to $S$. artedielli according to the SSU rDNA sequences, $S$. longa, differs clearly by having longer, slightly arcuate spores, with more rounded ends.

To provide a proper sequence comparison of $S$. artedielli with $S$. balbianii (see above), the type species of genus Sphaeromyxa, full-length SSU rDNA sequences of $S$. balbianii were obtained in this study. Two SSU rDNA sequence variants of a different length were found. These represent the first significant rDNA genomic variation to be reported in the phylum Myxozoa. Such sequence variation has been found frequently in some microsporidians (Lom et al. 2001, Tay et al. 2005) and in parasitic protists (e.g. Pecher et al. 2004). Such a large sequence variation has been attributed to the existence of pseudogenes in addition to functional rRNA genes (Lom et al. 2001, Pecher et al. 2004), but also to strand jumping during PCR amplification (Brown et al. 2004).

Another explanation for several rDNA variants in a single host specimen is multiple infections by different genotypes. Our data indicate that the shorter copy of the SSU rRNA gene most probably represents a pseudogene in the
S. balbianii genome. The basis for this interpretation is that a substantial part of the large deletion contains conservative regions of the SSU rDNA, and their lack certainly affects the function of the rRNA molecule. In addition to indels, the two copies of the SSU rDNA in S. balbianii also differ at a number of positions. Such polymorphism, normally seen as ambiguous signals, was also observed in $S$. artedielli and is common intragenomic variation in the Myxozoa (Bartošová et al. 2009, Køie et al. 2013).

The almost complete SSU rDNA sequences of $S$. artedielli obtained from the host species $A$. atlanticus and T. murrayi diverged by $1.1 \%$, but were found to be consistent within host species. This may suggest that these sculpins host particular genotypes of the myxosporean. Similar patterns have been seen in other Myxosporea (Atkinson et al. 2011, Bartošová and Fiala 2011, Køie et al. 2013). The clupeid fish species Sprattus sprattus (Linnaeus) and Clupea harengus Linnaeus are both infected by Parvicapsulidae gen. sp. and Ortholinea orientalis (Shul'man et Shul'man-Albova, 1953) in the northeast Atlantic, but apparently by particular genotypes of the parasites (Karlsbakk and Køie 2011, Køie et al. 2013). However, more intensive sampling is needed to substantiate these interesting patterns, which may relate to the existence of cryptic myxosporean species.

Phylogenetic analyses placed $S$. artedielli in a well supported clade containing members of the 'balbianii' group of the Sphaeromyxa clade, in a subclade together with $S$. longa. The inclusion of $S$. artedielli in the analyses supports a bipartition of species of the genus Sphaeromyxa into two clades (Kristmundsson and Freeman 2013, Whipps and Font 2013). These clades represent species morphologically belonging to the 'balbianii' and 'incurvata' groups of Laird (1953), respectively. The divergence in the SSU rDNA sequences between the members of the 'balbianii' group and those of the 'incurvata' group sequenced so far is large, $13-16 \%$. This suggests that these clades and morphological types should be assigned to different genera within the family Sphaeromyxidae. The arcuate spore shape, twisted valves and rounded spore ends may represent synapomorphies of the 'incurvata'clade.

However, a better basis for the establishment of such a taxon is needed; indeed some species appear to be intermediate. Since there are few developmental and morphological characters readily available in myxosporeans, molecular characters must also be considered. These may represent substitutions or indels in the conserved (core) parts of the rDNA (e.g. Bass et al. 2009) or size, composition and morphology of the often expanded variable regions in the Myxosporea (Holzer et al. 2007, Jirků et al. 2007). Therefore, a better coverage of the genus with respect to rDNA sequences is required.

A problem encountered in the present study, valid for many groups of parasites with few morphological charac- 
ters, is an expansion of the morphological species conception due to supplementary descriptions of a species from different hosts and localities worldwide. This applies to S. balbianii, which has been recorded from numerous species of shallow water fishes in Europe, West Africa, Atlantic and Pacific coast of North America and from Brazil. It is likely that these records from Arctic to tropical waters refer to several morphologically similar species 'of the 'balbianii' group, and sequence information would be valuable in order to distinguish as well as to characterize them. Therefore, to solve many of the taxonomic problems in the Myxosporea, redescriptions of many of the 'old' and poorly described species should include the material from their type hosts and the localities, accompanied with molecular data (preferably rDNA sequences).

Acknowledgements. The present study was supported by the Norwegian Biodiversity Information Centre Project No. 70184219 (E.K.), and by the Czech Science Foundation (P506/11/P724 to P.B.). We would like to thank Dr. Hana Pecková for technical assistance (Laboratory of Fish Protistology, Institute of Parasitology, BC ASCR).

\section{REFERENCES}

Aseeva N.L. 2002: New species of myxosporeans (Myxozoa, Myxosporea) from sculpins of the northwestern Japan Sea. Acta Parasitol. 47: 179-189.

Atkinson S.D., Jones S.R.M., Adlard R.D., Bartholomew J.L. 2011: Geographical and host distribution patterns of Parvicapsula minibicornis (Myxozoa) small subunit ribosomal RNA genetic types. Parasitology 138: 969-977.

Barta J.R., Martin D.S., Liberator P.A., Dashkevicz M., Anderson J.W., Feighner S.D., Elbrecht A., Perkins-Barrow A., Jenkins M.C., Danforth H.D., Ruff M.D., ProfousJuchelka H. 1997: Phylogenetic relationships among eight Eimeria species infecting domestic fowl inferred using complete small subunit ribosomal DNA sequences. J. Parasitol. 83: 262-271.

Bartošová P., Fiala I. 2011: Molecular evidence for the existence of cryptic species assemblages of several myxosporeans (Myxozoa). Parasitol. Res. 108: 573-583.

Bartošová P., Fiala I., Hypša V. 2009: Concatenated SSU and LSU rDNA data confirm the main evolutionary trends within myxosporeans (Myxozoa: Myxosporea) and provide an effective tool for their molecular phylogenetics. Mol. Phyl. Evol. 53: 81-93.

Bass D., Chao E.E.-Y., Nikolaev S., Yabuki A., Ishida K., Berneya C., Pakzad U., Wylezich C., Cavalier-Smith T. 2009: Phylogeny of novel naked filose and reticulose Cercozoa: Granofilosea cl. n. and Proteomyxidea revised. Protist 160: 75-109.

Brown G.D., Hudson K.L., Reece K.S. 2004: Multiple polymorphic sites at the ITS and ATAN loci in cultured isolates of Perkinsus marinus. J. Euk. Microbiol. 51: 312-320.

Diamant A., Whipps C.M., Kent M.L. 2004: A new species of Sphaeromyxa (Myxosporea: Sphaeromyxina: Sphaeromyxidae) in devil firefish, Pterois miles (Scorpaenidae), from the northern Red Sea: morphology, ultrastructure, and phylogeny. J. Parasitol. 90: 1434-1442.

Freeman M.A., Yokoyama H., Ogawa K. 2008: Description and phylogeny of Ceratomyxa anko sp. n. and Zschokkella lophii sp. n. from the Japanese anglerfish, Lophius litulon (Jordan). J. Fish Dis. 31: 921-930.

Gracia M.P., Maíllo P.A., Amigó J.M., Salvadó H. 1997: Ultrastructural study of Sphaeromyxa balbianii Thélohan 1892 (Myxozoa, Myxosporea: Bivalvulida), a parasite of Cepola macrophthalma Linnaeus, 1758. Acta Protozool. 36: 171-179.

Holzer A.S., Wootten R., Sommerville C. 2007: The secondary structure of the unusually long $18 \mathrm{~S}$ ribosomal RNA of the myxozoan Sphaerospora truttae and structural evolutionary trends in the Myxozoa. Int. J. Parasitol. 37: 1281-1295.
JirkỦ M., Fiala I., Modrý D. 2007: Tracing the genus Sphaerospora: rediscovery, redescription and phylogeny of the Sphaerospora ranae (Morelle, 1929) n. comb. (Myxosporea, Sphaerosporidae), with emendation of the genus Sphaerospora. Parasitology 134: 1727-1739.

Karlsbakk E., KøIE M. 2011: Morphology and SSU rDNA sequences of Ortholinea orientalis (Shul'man and Shul'man-Albova, 1953) (Myxozoa, Ortholineidae) from Clupea harengus and Sprattus sprattus (Clupeidae) from Denmark. Parasitol. Res. 109: 139-145.

Kent M.L., Khattra J., Hedrick R.P., Devlin R.H. 2000: Tetracapsula renicola $\mathrm{n}$. sp. (Myxozoa: Saccosporidae); the PKX myxozoan - the cause of proliferative kidney disease of salmonid fishes. J. Parasitol. 86: 103-111.

Khan R.A., Bowering W.R., Burgeois C., Lear H., Pippy J.H. 1986: Myxosporean parasites of marine fish from the continental shelf off Newfoundland and Labrador. Can. J. Zool. 64: 2218-2226.

Køie M., Karlsbakk E., Einen A.-C.B., Nylund A. 2013: A parvicapsulid (Myxozoa) infecting Sprattus sprattus and Clupea harengus (Clupeidae) in the Northeast Atlantic uses $\mathrm{Hy}$ droides norvegicus (Serpulidae) as invertebrate host. Folia Parasitol. 60: 149-154.

Køie M., Karlsbakk E., Nylund A. 2008: The marine herring myxozoan Ceratomyxa auerbachi (Myxozoa, Ceratomyxidae) uses Chone infundibuliformis (Annelida: Polychaeta: Sabellidae) as invertebrate host. Folia Parasitol. 55: 100-104.

Kovaleva A.A., Gaevskaya A.V. 1982: [New data on Myxosporidia from the south-western Atlantic fishes.] Parazitologiya 16: 353-359. (In Russian.)

Kristmundsson Á., Freeman M.A. 2013: Sphaeromyxids form part of a diverse group of myxosporeans infecting the hepatic biliary systems of a wide range of host organisms. Parasites \& Vectors 6: 51.

Laird M. 1953: The Protozoa of New Zealand intertidal zone fishes. Trans. Roy. Soc. New Zeal. 81: 79-143.

Lom J. 1970: Protozoa causing diseases in marine fishes. Am. Fish. Soc., Spec. Publ. 5: 101-123.

Lom J. 1984: Diseases caused by protistans. In: O. Kinne (Ed.), Diseases of Marine Animals. Vol. IV, Part 1. John Wiley \& Sons, Chichester, pp. 114-168.

Lom J. 2004: Morphology and ultrastructure of Sphaeromyxa noblei sp. n. (Myxozoa), parasite of Heteroclinus whiteleggii (Pisces) from Australian New South Wales coast. Folia Parasitol. 51: $19-26$.

Loм J., DyкоvÁ I. 1992: Protozoan Parasites of Fishes. Elsevier, Amsterdam, 315 pp. 
Lом J., Dyкоvé I. 2006: Myxozoan genera: definition and notes on taxonomy, life-cycle terminology and pathogenic species. Folia Parasitol. 53: 1-36.

LOM J., LAIRD M. 1969: Parasitic Protozoa from marine and euryhaline fish of Newfoundland and New Brunswick. I. Peritrichous ciliates. Can. J. Zool. 47: 1367-1380.

Lom J., Nilsen F., Dyková I. 2001: Thelohania contejeani Henneguy, 1892: dimorphic life cycle and taxonomic affinities, as indicated by ultrastructural and molecular study. Parasitol. Res. 87: $860-872$.

NAidenova N.N. 1970: [Parasite fauna of fishes in the family Gobiidae from the Azov Sea.] Biol. Morya, Kiev 20: 84-113. (In Russian.)

PARISI B. 1912: Primo contributo alla distribuzione geografica dei Missosporidi in Italia. Atti, Soc. Ital. Sci. Nat. Mus. Civ. 50: 283-299.

Pecher W.T., Robledo J.A.F., Vasta G.R. 2004: Identification of a second rRNA gene unit in the Perkinsus andrewsi genome. J. Euk. Microbiol. 51: 234-245.

Polyansky Yu.I. 1955: Parasites of the Fish of the Barents Sea. Trudy Zool. Inst. AN SSSR 19, 158 pp. (In Russian; English translation by Israel program for scientific translations, Jerusalem 1966.)

Sarkar N.K. 1999: Ortholinea gadusiae sp. n. and Sphaeromyxa opisthopterae sp. n. (Myxozoa: Myxosporea) from the clupeid fish of the Bay of Bengal, West Bengal, India. Acta Protozool. 38: $145-153$.

Sears B.F., Anderson P., Greiner E.C. 2011: A new species of myxosporean (Sphaeromyxidae), a parasite of lined seahorses,

Received 27 May 2013
Hippocampus erectus, from the Gulf of Mexico. J. Parasitol. 97: 713-716.

Shul'man S.S. 1966: Myxosporidian Fauna of the SSSR. Nauka, Moskva-Leningrad, 504 pp. (In Russian, English translation by Amerind Publishing Co., New Delhi, 1988, 631 pp.)

Tamura K., Peterson D., Peterson N., Stecher G., Nei M., Kumar S. 2011: MEGA5: Molecular Evolutionary Genetics Analysis using maximum likelihood, evolutionary distance, and maximum parsimony methods. Mol. Biol. Evol. 28: 27312739.

Tay W.T., O’Mahony E.M., Paxton R.J. 2005: Complete rRNA gene sequences reveal that the microsporidium Nosema bombi infects diverse bumblebee (Bombus spp.) hosts and contains multiple polymorphic sites. J. Euk. Microbiol. 52: 505-513.

Thélohan P. 1892: Myxosporidies de la vésicule biliaire des poissons. Espèces nouvelles. Compt. Rend. Hebd. Séanc. Acad. Sci., Paris 115: 1091-1094.

ThéLohan P. 1895: Recherches sur les Myxosporidies. Bull. Sci. France Belg. 26: 100-394.

Timi J.T., Sardella N.H. 1998: Myxosporeans and coccidians parasitic on engraulid fishes from the coasts of Argentina and Uruguay. Parasite 5: 331-339.

Whipps C.M., Font W.F. 2013: Interaction of two myxozoan parasites from naked goby Gobiosoma bosc, in Lake Pontchartrain, Louisiana. J. Parasitol. 99: 441-447.

Zнuкоv E.V. 1964: [Parasitofauna of fishes of Chukotka. III. Protozoa of marine and freshwater fishes. General conclusions.] Parazitol. Sbornik 22: 224-262. (In Russian.)

Accepted 7 July 2013 